\title{
Refined secondary-structure models of the core of yeast and human telomerase RNAs directed by SHAPE
}

\author{
RACHEL O. NIEDERER and DAVID C. ZAPPULLA \\ Department of Biology, Johns Hopkins University, Baltimore, Maryland 21218, USA
}

\begin{abstract}
Telomerase catalyzes the addition of nucleotides to the ends of chromosomes to complete genomic DNA replication in eukaryotes and is implicated in multiple diseases, including most cancers. The core enzyme is composed of a reverse transcriptase and an RNA subunit, which provides the template for DNA synthesis. Despite extensive divergence at the sequence level, telomerase RNAs share several structural features within the catalytic core, suggesting a conserved enzyme mechanism. We have investigated the structure of the core of the human and yeast telomerase RNAs using SHAPE, which interrogates flexibility of each nucleotide. We present improved secondary-structure models, refined by addition of five base triples within the yeast pseudoknot and an alternate pairing within the human-specific element J2a.1 in the human pseudoknot, both of which have implications for thermodynamic stability. We also identified a potentially structured CCC region within the template that may facilitate substrate binding and enzyme mechanism. Overall, the SHAPE findings reveal multiple similarities between the Saccharomyces cerevisiae and Homo sapiens telomerase RNA cores.
\end{abstract}

Keywords: TLC1; hTR; chemical probing; IncRNA; ncRNA; telomerase RNA; SHAPE; RNP; telomerase; RNA

\section{INTRODUCTION}

Telomerase is a ribonucleoprotein (RNP) that catalyzes the addition of telomere repeats to the ends of eukaryotic chromosomes, which cannot be completely copied by DNAdependent DNA polymerases. Although telomerase is expressed at extremely low levels in most somatic cells, it is active in early development and in the germline and is found to be up-regulated in $>90 \%$ of cancers (Shay 1997; Heaphy et al. 2011). Thus, there is intense interest in telomerase as a potential drug target for treating cancers, since its activity is critical for unlimited cell proliferation potential. Additionally, multiple diseases have been linked to mutations in the RNA and protein subunits (Blasco 2005).

Although the telomerase holoenzyme consists of multiple protein subunits, which can vary between species, all telomerase enzymes minimally contain a reverse transcriptase (TERT) and an RNA component, which provides the template for reverse transcription. The TERT and the RNA subunit are sufficient for basal telomerase activity in vitro (Weinrich et al. 1997; Zappulla et al. 2005). In addition to providing the template, telomerase RNA also serves as a scaffold for assembling the protein subunits to form the RNP. These accessory subunits, many of which are essential, are involved in various aspects of telomerase function including telomere recruitment, trafficking, regulation, and processing.

Corresponding author: zappulla@jhu.edu

Article published online ahead of print. Article and publication date are at http://www.rnajournal.org/cgi/doi/10.1261/rna.048959.114.
In Saccharomyces cerevisiae, all accessory protein binding sites can be repositioned with retention of function in vivo, illustrating that the 1157-nt yeast telomerase RNA, TLC1, is a flexible scaffold (Zappulla and Cech 2004; Zappulla et al. 2011; Mefford et al. 2013).

Large portions of the yeast and human RNAs outside of the core region are dispensable for activity. In yeast, the bulk of the three long TLC1 RNA arms can be removed to form 384-500-nt Mini-T alleles that still function in vivo and allow yeast telomerase reconstitution in vitro (Zappulla et al. 2005). The arms are entirely dispensable for in vitro activity, since a further-miniaturized allele consisting only of the 170-nt core is also able to reconstitute activity to Mini-T levels (Qiao and Cech 2008), indicating that the core is the only portion required for basal activity. For the human enzyme, in vitro activity can be reconstituted by similarly combining TERT with RNA core nucleotides 33-191, although human telomerase also requires an 87-nt element outside its core, CR4/5, either provided in trans or tethered to the core (Autexier et al. 1996; Mitchell and Collins 2000; Wu and Collins 2014).

Despite extensive divergence of telomerase RNA in sequence and length (spanning from $147 \mathrm{nt}$ in a ciliate species

(C) 2015 Niederer and Zappulla This article is distributed exclusively by the RNA Society for the first 12 months after the full-issue publication date (see http://rnajournal.cshlp.org/site/misc/terms.xhtml). After 12 months, it is available under a Creative Commons License (Attribution-NonCommercial 4.0 International), as described at http://creativecommons.org/licenses/by$\mathrm{nc} / 4.0 /$. 
to $>2 \mathrm{~kb}$ in some fungi), most telomerase RNAs share four common structural elements within the central catalytic core, including the template, a template-boundary element, a core-enclosing helix, and a catalytically important pseudoknot (Lin et al. 2004; Mefford et al. 2013). In the core of TLC1, the elements are functionally linked by an Area of Required Connectivity (Mefford et al. 2013). The high conservation of telomerase RNA core structures in spite of rapid evolution of the RNA overall suggests that the cores function similarly.

The pseudoknot of TLC1 and human telomerase RNA (hTR) are both large, unlike that of the small ciliate telomerase RNAs. In both S. cerevisiae and $H$. sapiens, the pseudoknot exists in an equilibrium in vitro with an alternate twostem-loop conformation (Theimer et al. 2003; Liu et al. 2012). Mutations that promote the stem-loop conformation are associated with the disease dyskeratosis congenita (Vulliamy et al. 2001), which is characterized by defects in highly proliferative tissues (Dokal 2000), indicating a possible disruption of telomere maintenance. This underscores the importance of appropriate pseudoknot formation in vivo. Another important feature of both the human and yeast pseudoknots is a set of base triples, which have been shown to be in close proximity to the template (Theimer et al. 2005; Qiao and Cech 2008). In yeast, the base triples contribute directly to catalysis through an unknown mechanism (Qiao and Cech 2008). One difference between the TLC1 and hTR cores is that whereas TLC1 has both a template boundary-defining helix (Tzfati et al. 2000; Seto et al. 2002) and a core-enclosing helix (Dandjinou et al. 2004; Lin et al. 2004; Zappulla and Cech 2004), hTR has a single paired element that contributes to both of these functions (Chen and Greider 2003).

Despite the great interest in telomerase in biomedical research, the three-dimensional structure of the catalytic core of telomerase RNA remains unknown. Only the structures of isolated elements have been solved by NMR (Leeper et al. 2003; Leeper and Varani 2005; Theimer et al. 2005, 2007; Chen et al. 2006; Richards et al. 2006a,b; Kim et al. 2008, 2010, 2014; Zhang et al. 2010, 2011). Although there have been some previous chemical structure-probing analyses of telomerase RNAs (Antal et al. 2002; Forstemann and Lingner 2005), even secondary-structure models have been difficult to validate or refine. In this study, we examine the entire catalytically competent core region of both the yeast and human telomerase RNA using Selective 2' -hydroxyl acylation analyzed by Primer Extension (SHAPE), which interrogates the flexibility of each nucleotide (Merino et al. 2005; Wilkinson et al. 2006). We present SHAPE-directed secondary-structure models for both the yeast and human telomerase RNA cores, including newly suggested pairings in their pseudoknots. In comparing the SHAPE-reactivity patterns of each RNA, we also identified conserved patterns in reactivity with potential implications for enzyme coordination. The single-nucleotide resolution of the entire human and yeast telomerase RNA cores provides improved precision in understanding conserved catalytic core structure and enzyme action.

\section{RESULTS AND DISCUSSION}

Structural characterization of the $S$. cerevisiae telomerase RNA, TLC1, has been challenging due to its large size, the rapid structural evolution of even essential core RNA elements and their considerable mutational tolerance (Livengood et al. 2002; Lin et al. 2004; Zappulla et al. 2005; Lebo and Zappulla 2012; Mefford et al. 2013). A range of secondary-structure models have been proposed for the essential pseudoknot within the catalytic core (Supplemental Fig. 1), as well as other regions (Dandjinou et al. 2004; Zappulla and Cech 2004; Qiao and Cech 2008; Gunisova et al. 2009; Liu et al. 2012; Qi et al. 2013). A biochemical approach would add clarity and help overcome such obstacles. To more specifically investigate the structure of the conserved catalytic core, we optimized folding conditions for the 170-nt yeast telomerase RNA, Micro-TLC1 (Qiao and Cech 2008), and examined its structure by SHAPE chemical mapping. Together with TERT, Micro-TLC1 is able to reconstitute telomerase activity in vitro.

The SHAPE results show that both the pseudoknot and a single-stranded template of the yeast telomerase RNA core form in vitro, even in the absence of TERT. This is in contrast to the reported behavior of the Tetrahymena RNA and the full-length human RNA (Yeoman et al. 2010; Mihalusova et al. 2011; Cole et al. 2012). The predicted stems of the template-boundary element and pseudoknot show reproducibly low reactivity, as expected for base-paired nucleotides, whereas there is higher reactivity in most junctions and loops. Overall, the SHAPE-supported secondary-structure model in Figure 1 is largely consistent with the previously observed DMS-reactivity pattern in the pseudoknot of full-length, protein-bound TLC1 (Forstemann and Lingner 2005), and therefore protein binding may not influence the conformation of the yeast pseudoknot to a great extent.

The junctions within the yeast core are generally reactive, with every nucleotide in $\mathrm{J} 3$ and $\mathrm{J} 4$ being modified. These regions may introduce considerable physical flexibility in the core, particularly $\mathrm{J} 3$, which is $16 \mathrm{nt}$ long and tolerates a wide variety of mutations (Mefford et al. 2013). However, both $\mathrm{J} 1$ and $\mathrm{J} 2$ are comparatively less reactive (Fig. 1). Interestingly, while we observe reactivity within the template, nucleotides 44-46 (CCC) consistently did not show reactivity above background levels, suggesting they may be stacked or involved in tertiary interactions. Polycytidylic acid alone can form a helix stabilized by base stacking or hydrogen bonding between adjacent bases (Arnott et al. 1976; Freier et al. 1981; Broido and Kearns 1982; Tubbs et al. 2013). The CCC residues within the template could be adopting a similar structure, resulting in low NMIA reactivity. The structured CCC residues could also be related to NMIA- 
A
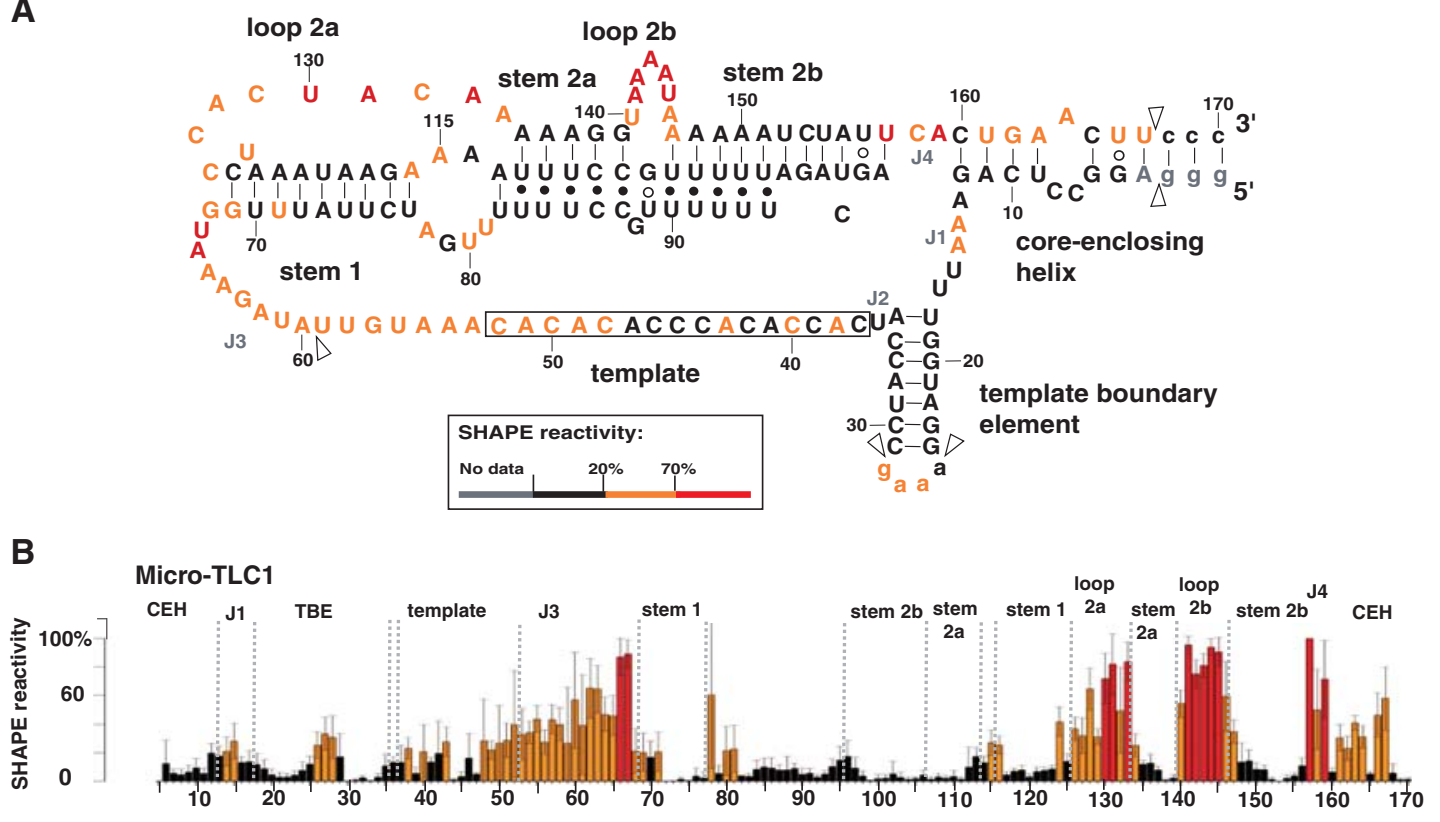

FIGURE 1. SHAPE-directed secondary-structure model of the core of S. cerevisiae telomerase RNA. $(A)$ The refined yeast telomerase RNA secondarystructure model incorporating SHAPE results. GU wobble pairs indicated by open circles. Other non-Watson-Crick interactions are denoted with filled circles. Open triangles correspond to deletions relative to TLC1 and exogenous sequence is lowercase. (B) SHAPE reactivity at each position in the yeast telomerase RNA core. Values represent the average of between 5 and 18 independent trials with standard error shown.

independent reverse transcriptase pausing at some of the neighboring nucleotides.

To test the SHAPE-supported pseudoknot model, we designed two pseudoknot-disrupting mutants, dmPK-1 and dmPK-2. Each mutant has $7 \mathrm{nt}$ on each side of stem 1 changed to its Watson-Crick cognate, which is predicted to abolish base-pairing with minimal disruption to proposed alternate conformations (Fig. 2A; Zappulla and Cech 2004; Liu et al. 2012). Both mutants dmPK-1 and -2 showed severely reduced telomerase activity in vitro (Fig. 2C) and an increase in SHAPE reactivity throughout stem 1 , showing that the mutations disrupted pseudoknot formation (Fig. 2B). While both mutants disrupt pseudoknot formation, they do not appear to result in the same RNA conformation (Fig. 2B). In contrast, the double-mutant allele (dmPK-R) showed greater telomerase activity than either single mutant and NMIAreactivity restored to that of wild type. These results support the conclusion that the pseudoknot is forming in vitro and provide further evidence that it is important for activity.

These data strongly support the formation of five additional base triples within the pseudoknot (nucleotides 8387, 108-112, and 135-139), which we name "stem 2a." The structure is phylogenetically supported (Supplemental Fig. 1 ), however, mutations in this region in the context of larger yeast telomerase RNAs have resulted in only a slight decrease in activity in vivo and in vitro (Lin et al. 2004; Shefer et al. 2007; Qiao and Cech 2008). These base triples have been previously proposed based on thermodynamic characterization and were observed in Kluyveromyces lactis (Liu et al. 2012;
Cash et al. 2013) and their main function is likely to favor pseudoknot formation and stability without directly contributing to catalysis.

To investigate the nature and importance of the five base triples, we first mutated the $3^{\prime}$-most and middle two strands to their Watson-Crick cognate. In both cases, the mutations greatly decreased telomerase activity (Supplemental Fig. 2C). Combining these changes in a compensatory mutant reduced telomerase activity further and did not return the wild-type SHAPE-reactivity pattern, indicating the base-compensatory Watson-Crick interaction had not formed (Supplemental Fig. 2B). However, the low SHAPE reactivity of the $5^{\prime}$ and middle strands in the double mutant is consistent with these mutations simply lengthening stem 1 of the pseudoknot. Therefore, in the next mutation strategy, we instead changed the three $\mathrm{U}-\mathrm{A} \cdot \mathrm{U}$ predicted triples to $\mathrm{C}-\mathrm{G} \cdot \mathrm{C}$, and vice versa for the other two triples to generate the best structural mimic of the wild-type interactions. We also made the single- and double-mutant-strand combinations. Again, we observed decreased telomerase activity for many of the mutants, including the triple-strand substitution allele (Supplemental Fig. 2C). We conclude from these results that the native sequence of each of these three strands is important for activity. X-ray crystallography and/or NMR studies on the S. cerevisiae pseudoknot region should help reveal the nature and geometry of these interactions more precisely. Finally, it appears that this structure is more important for telomerase function in the context of Micro-T RNA than it is in longer TLC1 alleles (Lin et al. 2004; Qiao and Cech 2008). 
A

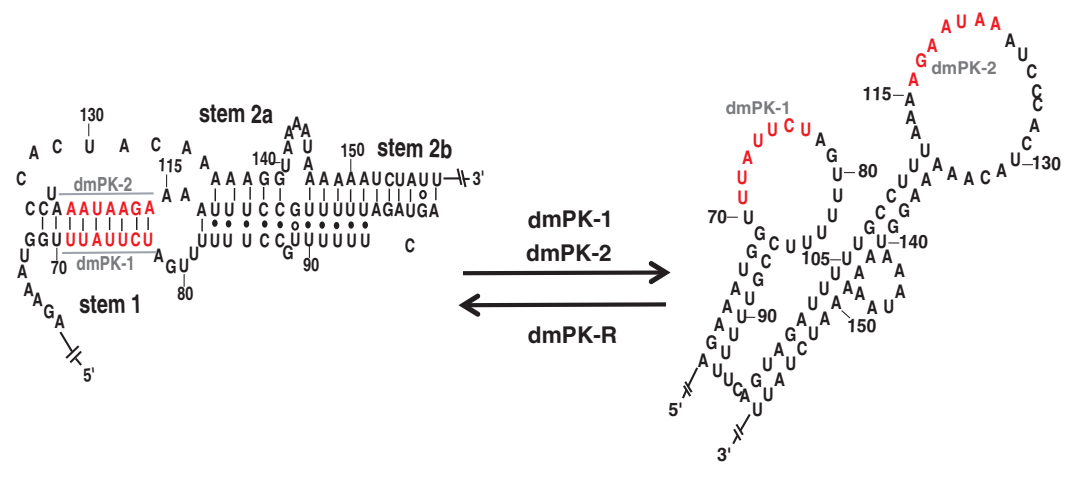

B

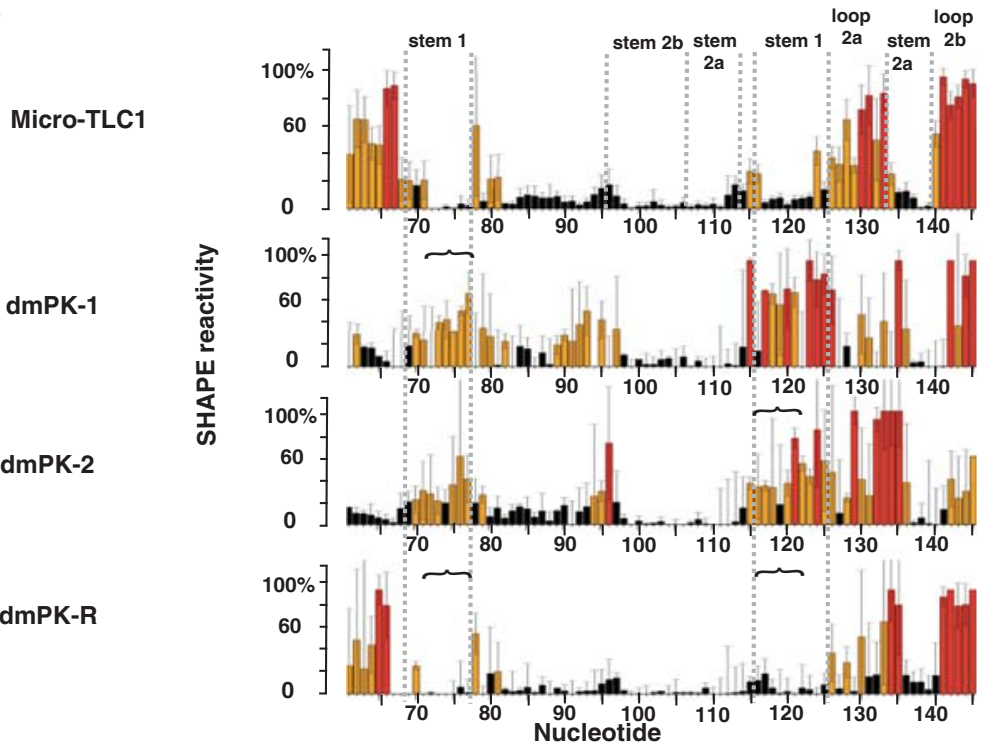

C

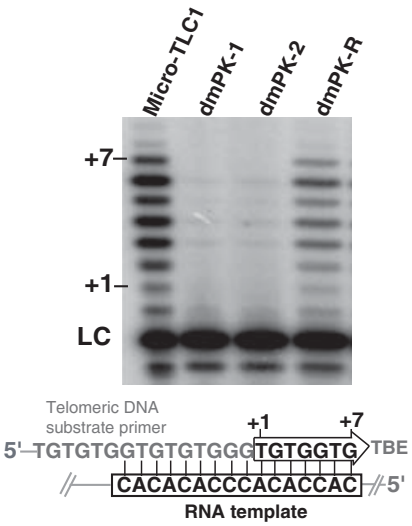

FIGURE 2. Pseudoknot-disrupting mutants increase reactivity in stem 1. (A) Design of pseudoknot-disrupting mutants. Seven nucleotides in stem 1 were mutated to their Watson-Crick cognate to abolish base-pairing. The mutations are predicted to disrupt pseudoknot formation without affecting the alternately observed two stem-loop conformation (Liu et al. 2012) (right). Pseudoknot-disrupting mutants are indicated as dmPK-1 and dmPK-2. (B) SHAPE reactivity in WT and PK-disrupting mutants. SHAPE reactivity is plotted for WT (from Fig. 1), both PK-disrupting mutants and the stem 1 restoring mutant dmPK-R. Reactivities for dmPK-1, dmPK-2, and dmPK-R correspond to the average value between 3 and 9 independent trials with standard deviation shown. Mutated nucleotides are indicated by brackets. $(C)$ Pseudoknot-disrupting mutants decrease telomerase activity in vitro. Telomerase assay testing activity of PK and compensatory mutants. Alignment of DNA primer with TLC1 is shown. (TBE) template-boundary element.

To explore evolutionarily conserved structure-function relationships within telomerase, we next examined the folding of the human telomerase RNA core. We focused on nucleotides 33-191 of the human RNA, hTR, which reconstitute telomerase activity in vitro when expressed in a transcription-translation system with the CR4/5 domain and hTERT (Ly et al. 2003). We find that SHAPE results with the core of hTR are generally consistent with current structural models and suggest that the RNA alone is able to form a catalytically competent structure with both a pseudoknot and a single-stranded template (Fig. 3; Theimer et al. 2005; Kim et al. 2008; Zhang et al. 2011; Hengesbach et al. 2012). We observe high reactivity of nucleotides throughout J2a/3 and, reciprocally, generally low reactivity throughout each pseudoknot stem. Interestingly, the region surrounding the proposed catalytically important "hinge-point" at J2a/b
(Zhang et al. 2010) is reactive, suggesting this location may be particularly dynamic, or else held in a reactive conformation due to a unique, conserved local structure (Zhang et al. 2010).

The junctions in hTR show a similar reactivity pattern to the yeast core, with reactive nucleotides in the region $3^{\prime}$ of the template and between P1b and P3 (J4 in yeast) (Fig. 3 ). Again, we see a region of low reactivity $5^{\prime}$ of the template where it has been shown that length but not sequence is important for template-boundary definition (Chen and Greider 2003), suggesting a potential structural role for these nucleotides in this process. Furthermore, we see nucleotides 50-52 (CCC) within the template are unreactive, which is consistent with previous work (Antal et al. 2002) and the yeast RNA (see above and Fig. 1A). The equivalent CCC nucleotides are also unreactive in SHAPE studies on the active TERT-bound 
A



template

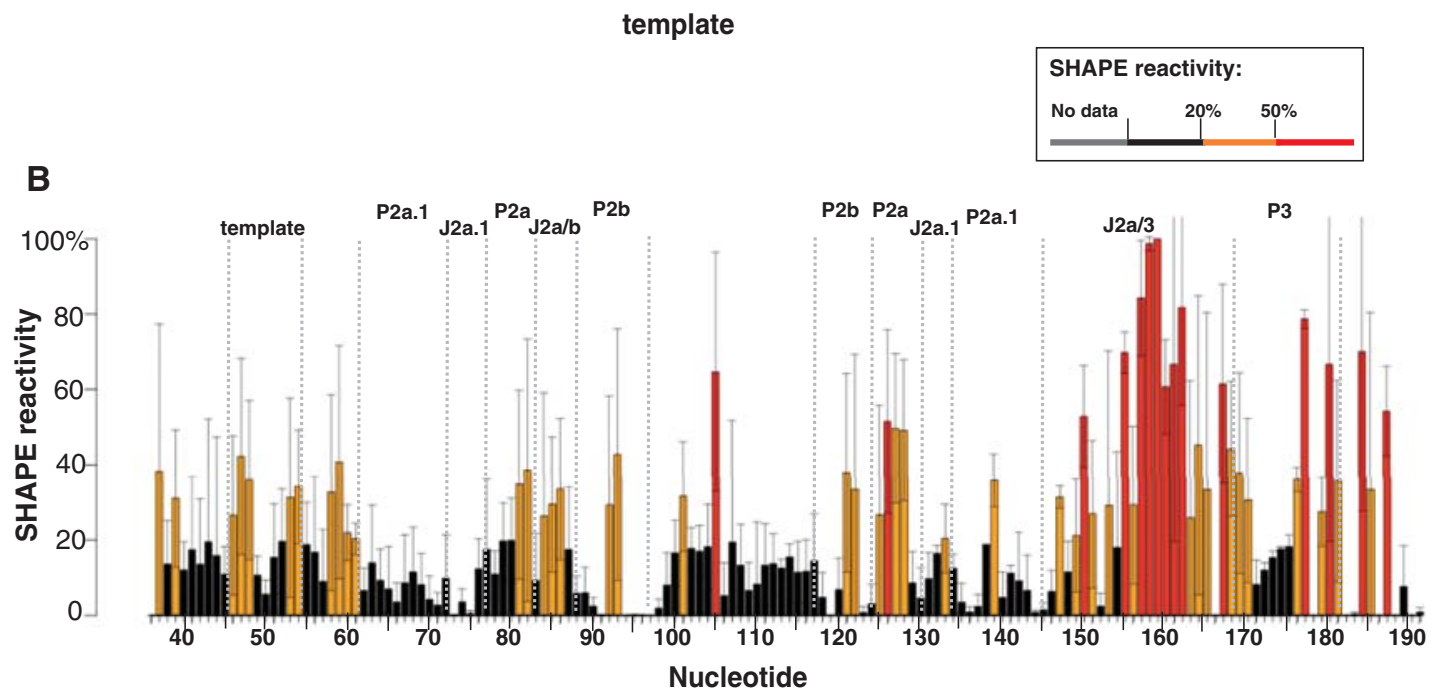

FIGURE 3. SHAPE-refined secondary-structure model of the H. sapiens core. (A) SHAPE reactivity mapped onto hTR secondary structure. NonWatson-Crick interactions indicated by circles with GU wobble pairs denoted by open circles. Hoogsteen-face interaction is denoted with square. Dashed lines indicate reactive residues previously shown to pair in vitro (Zhang et al. 2011). (B) SHAPE reactivity by nucleotide. Values represent the average of between 6 and 12 independent trials. Standard error is shown.

Tetrahymena telomerase RNA conformation, so this may be an additional conserved structural feature of telomerase RNAs (Cole et al. 2012). In yeast, these nucleotides are known to be in close proximity to the catalytically important base triples when bound to a DNA substrate and FRET studies of hTR also suggest that the template is near the base triples (Qiao and Cech 2008). In all three species, the extendable $3^{\prime}$ end of the telomere likely consists of between one to four G nucleotides that anneal to the CCC residues described. This suggests the template may be preorganized structurally to favor productive annealing and to specifically position the extendable end of the substrate within the RNP active site (see Fig. 4).

Pseudoknot formation in hTR requires magnesium (Hengesbach et al. 2012), so to investigate the structure of the core we next sought to identify and characterize elements that show magnesium-dependent folding. In the absence of magnesium, we observed two major RNA conformations by native gel (Supplemental Fig. 3A), suggesting the core of hTR RNA exists in an equilibrium between two folded states, consistent with previous work on the pseudoknot alone (Theimer et al. 2003). This indicates the pseudoknot is the structural element primarily driving this equilibrium. We observe an overall decrease in reactivity in the $\mathrm{P} 2 \mathrm{~b} / \mathrm{P} 3$ pseudoknot region as magnesium concentration increases, supporting the conclusion that $\mathrm{Mg}^{2+}$ promotes pseudoknot formation (Supplemental Fig. 3B). We also find that the disease-associated allele $\mathrm{hTR}^{\mathrm{DKC}}$ (nucleotides 108 and 109, CG $\rightarrow$ GA) exhibits two bands like those present in wild-type hTR, although equilibrium between the two appears unaffected by magnesium, consistent with previous observations (Supplemental Fig. 3; Hengesbach et al. 2012).

The SHAPE data in optimized magnesium are consistent with a fully formed P2a.1 region leading into a surprisingly unreactive J2a.1. Here we propose three additional base pairs form, resulting in a 12-bp long P2a.1 and a smaller J2a.1, as shown in Figure 3A. Previous work has suggested J2a.1 can adopt alternate base-pairing conformations in vitro, though mutational and phylogenetic analyses indicate that any pairing is dispensable (Chen et al. 2000; Martin-Rivera and Blasco 2001; Zhang et al. 2011). 
A

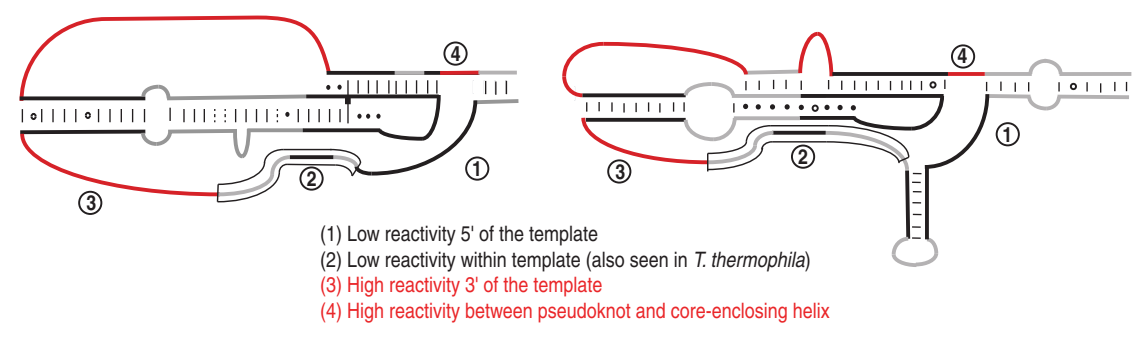

B

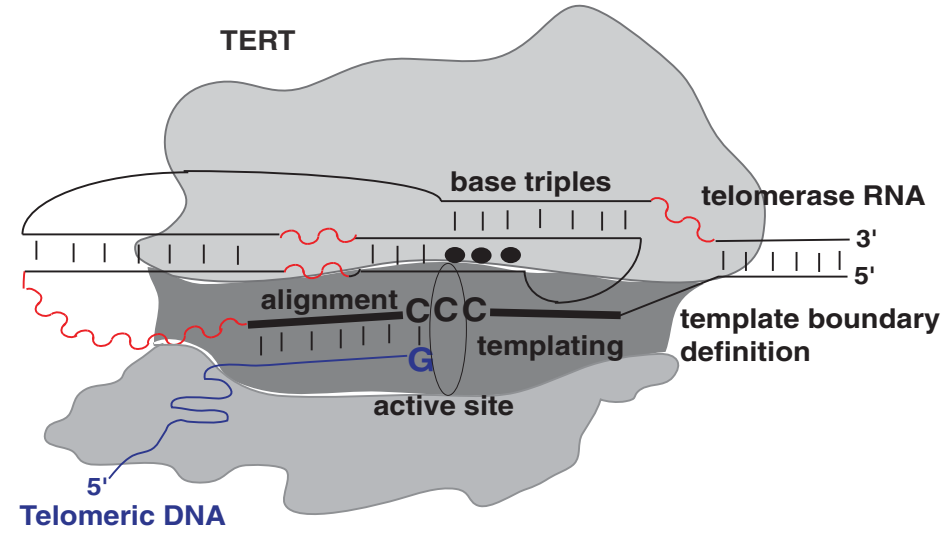

FIGURE 4. Models of the yeast and human TR cores. (A) Micro-TLC1 and the hTR core show similar reactivity patterns. Summary diagram of general reactivity patterns for each core. Regions of low reactivity common to both hTR and Micro-TLC1 are shown in black, while common regions of high reactivity are colored red. $(B)$ A general model for telomerase RNA core domain coordination with TERT. A generic telomerase RNA core with common structural elements is shown. Regions that may introduce physical flexibility based on SHAPE data are highlighted in red. The potential conserved structural element consisting of CCC nucleotides in the template is drawn in proximity to the catalytically important base triples and ending in the active site, shown as an open oval. The template is indicated by a thick line. Telomeric DNA is shown in blue.

Comparing the reactivity patterns in hTR and MicroTLC1, we note several similarities (Fig. 4A). Both RNAs exhibit comparatively low reactivity $5^{\prime}$ of the template and higher reactivity $3^{\prime}$ of the template and between the pseudoknot and core-enclosing helix. These elements could coordinate positioning of the template near the catalytically important base triples with the reactive regions serving as flexible tethers while the potentially structured area $5^{\prime}$ of the template acts as an anchored template-boundary element.

In summary, we present secondary-structure models refined by SHAPE analysis that include base-triple interactions in the yeast core additional to those previously implicated in catalysis (Qiao and Cech 2008) and an alternate conformation within hTR J2a.1. In so doing, we have also shown that the cores of both yeast and human telomerase RNAs independently adopt their native conformation, as indicated by formation of the pseudoknot, base triples, and a singlestranded template. This is in contrast to the in vitro folding of the T. thermophila telomerase RNA, which was shown to require TERT to adopt an active conformation (Mihalusova et al. 2011; Cole et al. 2012). The ciliate pseudoknot is small and may lack stable base triples, potentially making its folding more proteindependent (Mihalusova et al. 2011; Cole et al. 2012). Finally, we also note a conserved region of low reactivity within the template of telomerase RNAs suggesting a mechanism to favor substrate binding and subsequent positioning near the catalytically important base triples within the TERT active site.

\section{MATERIALS AND METHODS}

\section{RNA preparation}

To obtain data at the $3^{\prime}$ end of the RNAs, templates were designed with an additional sequence cassette at the $3^{\prime}$ end as previously described (Supplemental Fig. 3; Wilkinson et al. 2006). In vitro transcription templates of Micro-TLC1 and hTR were prepared by FokI digestion of the corresponding pUC19 plasmids, while templates containing the RNA structure cassette were generated by PCR amplification. RNAs were purified by excising them from denaturing polyacrylamide gels and isolated by phenol-chloroform extraction followed by ethanol precipitation.

\section{SHAPE analysis}

Two picomoles of Micro-TLC1 or hTR 33191 constructs were suspended in $12 \mu \mathrm{L}$ $0.5 \times \mathrm{TE} \mathrm{pH} 8.0$ and subsequently denatured at $95^{\circ} \mathrm{C}$ for $2 \mathrm{~min}$, then cooled on ice for 3 min. Micro-TLC1 constructs were folded by treatment on ice with $6 \mu \mathrm{L} 3.3 \times$ folding buffer (333 mM HEPES, pH 8.0, $333 \mathrm{mM}$ $\mathrm{NaCl}, 20 \mathrm{mM} \mathrm{MgCl}_{2}$ ). hTR 33-191 constructs were folded in the same manner but with a modified $3.3 \times$ folding buffer $(333 \mathrm{mM}$ HEPES, pH 8.0, $333 \mathrm{mM} \mathrm{NaCl}, 33 \mathrm{mM} \mathrm{MgCl}_{2}$ ). Folded RNAs were divided and treated with either $1 \mu \mathrm{L} 65 \mathrm{mM} \mathrm{N}$-methylisatoic anhydride (NMIA) (Sigma) in anhydrous DMSO or $1 \mu \mathrm{L}$ DMSO. Modification reactions were carried out at $37^{\circ} \mathrm{C}$ for $22 \mathrm{~min}$ (Steen et al. 2012). Reaction volumes were then adjusted to $100 \mu \mathrm{L}$ with $0.2 \mathrm{M} \mathrm{NaCl}, 2 \mathrm{mM}$ EDTA, pH 8.0 and $0.2 \mathrm{mg} / \mathrm{mL}$ glycogen; the modified RNA was then ethanol precipitated and resuspended in $9 \mu \mathrm{L} 0.5 \times \mathrm{TE} \mathrm{pH} 8.0$.

Primer extension reactions were carried out as described in the SuperScript III reverse transcriptase protocol (Invitrogen) with the following modifications. One picomol of each RNA was denatured at $95^{\circ} \mathrm{C}$ for $1 \mathrm{~min}$ and placed on ice for $2 \mathrm{~min}$. Three microliters of $\left[\gamma^{32} \mathrm{P}\right]$-end-labeled primer was added and the solution was incubated at $65^{\circ} \mathrm{C}$ for $2 \mathrm{~min}$ followed by annealing at $35^{\circ} \mathrm{C}$ for $10 \mathrm{~min}$. Six microliters of the supplied SuperScript III buffer supplemented with $5 \mathrm{mM}$ DTT (final concentration) and $1 \mathrm{mM}$ dNTPs (final concentration) was added to the mixture, which was then preheated for 1 $\min$ at $52^{\circ} \mathrm{C}$. One hundred units of SuperScript III were added to each reaction at room temperature. Reactions were then incubated 
at $52^{\circ} \mathrm{C}$ for $5 \mathrm{~min}$ prior to running on a $10 \%$ polyacrylamide/ $1 \times$ TBE/7 M urea gel at $90 \mathrm{~W}$. Gel electrophoresis was performed for between 1.75 and $4 \mathrm{~h}$ to obtain appropriate resolution of each given region of the RNAs in order to quantify reactivity of individual nucleotides to NMIA. Gels were exposed on a phosphorimager screen, and imaged using a Typhoon 9410 Variable Mode Imager. Representative gels are shown in Supplemental Figure 4.

Modification intensities were measured using SAFA software (Das et al. 2005). Results were scaled by selecting the least-variable band across lanes, calculating lane-by-lane normalization factors to make the reference band equal across all lanes and scaling each lane accordingly. Normalized SHAPE reactivity was calculated by subtracting the intensity of the corresponding DMSO-only band from the NMIA band. To quantify the SHAPE reactivity, the average of the 10 most-reactive bands was set as $100 \%$ reactivity and all other bands were scaled accordingly (negative values were set to zero). Data were averaged from multiple experiments as indicated and were obtained using RNA from at least three independent transcription reactions. All RNAs were folded independently as described above.

\section{Secondary-structure model generation}

SHAPE-guided secondary-structure refinement was achieved by first mapping relative SHAPE-reactivities onto the most recent models. Inconsistencies between the SHAPE data and the model for the RNA were resolved using SHAPE-constrained secondarystructure predictions by "RNAstructure" (Deigan et al. 2009). In the event of a mismatch (e.g., 1 nt of a predicted base pair is reactive while the other is not) pairing status was left as described by current models.

\section{Telomerase assays}

Telomerase assays were performed essentially as previously described (Zappulla et al. 2005). Briefly, DNA template encoding Pro-A tagged Est2 (TERT) and telomerase RNA were added to the coupled rabbit reticulocyte lysate (RRL) transcription and translation system containing T7 RNA polymerase (Promega). Telomerase was immunopurified using IgG Sepharose beads (GE Healthcare). Telomerase activity was assayed by incubating $5 \mu \mathrm{L}$ of bead-bound enzyme with $1 \mu \mathrm{M}$ telomeric DNA substrate primer (DZ427), 1 $\mathrm{nM}\left[\gamma^{-}{ }^{32} \mathrm{P}\right]$-labeled primer DZ428 as a recovery and loading control, $3.3 \mu \mathrm{M}\left[a-{ }^{32} \mathrm{P}\right]-\mathrm{dGTP}, 1 \mu \mathrm{M}$ each dATP, dCTP, and dTTP, in 38 $\mathrm{mM}$ Tris pH 8, $47 \mathrm{mM} \mathrm{NaCl}, 4.7 \%$ glycerol, $2.2 \mathrm{mM} \mathrm{MgCl}_{2}, 0.5$ $\mathrm{mM}$ spermidine, and $0.5 \mathrm{mM}$ DTT. Reactions were incubated for $10 \mathrm{~min}$ at $26^{\circ} \mathrm{C}$ and subsequently stopped by the addition of ammonium acetate. Products were then ethanol precipitated and resuspended in $1 \times$ formamide loading buffer. The products were run through a $10 \%$ polyacrylamide/ $1 \times \mathrm{TBE} / 7 \mathrm{M}$ urea denaturing gel at $90 \mathrm{~W}$ for $1.25 \mathrm{~h}$, exposed on a phosphorimager screen, and imaged using a Typhoon 9410 Variable-Mode Imager.

\section{Native gel analysis}

Renatured RNAs were mixed with nondenaturing loading dye and run on a $5 \%$ polyacrylamide/ $1 \times \mathrm{TBE}$ gel for $3 \mathrm{~h}$ at $70 \mathrm{~W}$ at $4^{\circ} \mathrm{C}$. Gels were stained using Gel Star (Lonza) and imaged using a Typhoon 9410 Variable-Mode Imager.

\section{SUPPLEMENTAL MATERIAL}

Supplemental material is available for this article.

\section{ACKNOWLEDGMENTS}

We thank Sarah Woodson for help with SHAPE optimization, Tom Cech for the wild-type hTR plasmid, and Quentin Vicens for comments on the manuscript. We also thank Melissa Mefford and the rest of the Zappulla laboratory for experimental advice and general feedback on the manuscript. This work was supported by US National Institutes of Health funding from R00 GM80400 to D.C.Z. as well as startup funds from The Johns Hopkins University. R.O.N. was supported by National Institutes of Health Cellular and Molecular Biology graduate student training grant 2T32 GM007231.

Received October 31, 2014; accepted November 14, 2014.

\section{REFERENCES}

Antal M, Boros E, Solymosy F, Kiss T. 2002. Analysis of the structure of human telomerase RNA in vivo. Nucleic Acids Res 30: 912-920.

Arnott S, Chandrasekaran R, Leslie AG. 1976. Structure of the singlestranded polyribonucleotide polycytidylic acid. J Mol Biol 106: 735-748.

Autexier C, Pruzan R, Funk WD, Greider CW. 1996. Reconstitution of human telomerase activity and identification of a minimal functional region of the human telomerase RNA. EMBO J 15: 59285935.

Blasco MA. 2005. Telomeres and human disease: ageing, cancer and beyond. Nat Rev Genet 6: 611-22.

Broido MS, Kearns DR. 1982. H-1-NMR evidence for a left-handed helical structure of poly(ribocytidylic acid) in neutral solution. J Am Chem Soc 104: 5207-5216.

Cash DD, Cohen-Zontag O, Kim NK, Shefer K, Brown Y, Ulyanov NB, Tzfati Y, Feigon J. 2013. Pyrimidine motif triple helix in the Kluyveromyces lactis telomerase RNA pseudoknot is essential for function in vivo. Proc Natl Acad Sci 110: 10970-10975.

Chen JL, Greider CW. 2003. Template boundary definition in mammalian telomerase. Genes Dev 17: 2747-2752.

Chen JL, Blasco MA, Greider CW. 2000. Secondary structure of vertebrate telomerase RNA. Cell 100: 503-514.

Chen Y, Fender J, Legassie JD, Jarstfer MB, Bryan TM, Varani G. 2006. Structure of stem-loop IV of Tetrahymena telomerase RNA. EMBO J 25: 3156-3166.

Cole DI, Legassie JD, Bonifacio LN, Sekaran VG, Ding F, Dokholyan NV, Jarstfer MB. 2012. New models of Tetrahymena telomerase RNA from experimentally derived constraints and modeling. J Am Chem Soc 134: 20070-20080.

Dandjinou AT, Lévesque N, Larose S, Lucier JF, Abou Elela S, Wellinger RJ. 2004. A phylogenetically based secondary structure for the yeast telomerase RNA. Curr Biol 14: 1148-1158.

Das R, Laederach A, Pearlman SM, Herschlag D, Altman RB. 2005. SAFA: semi-automated footprinting analysis software for highthroughput quantification of nucleic acid footprinting experiments. RNA 11: 344-354.

Deigan KE, Li TW, Mathews DH, Weeks KM. 2009. Accurate SHAPEdirected RNA structure determination. Proc Natl Acad Sci 106: 97-102.

Dokal I. 2000. Dyskeratosis congenita in all its forms. Br J Haematol 110: 768-779.

Forstemann K, Lingner J. 2005. Telomerase limits the extent of base pairing between template RNA and telomeric DNA. EMBO Rep 6: 361-366. 
Freier SM, Hill KO, Dewey TG, Marky LA, Breslauer KJ, Turner DH. 1981. Solvent effects on the kinetics and thermodynamics of stacking in poly(cytidylic acid). Biochemistry 20: 1419-1426.

Gunisova S, Elboher E, Nosek J, Gorkovoy V, Brown Y, Lucier JF, Laterreur N, Wellinger RJ, Tzfati Y, Tomaska L. 2009. Identification and comparative analysis of telomerase RNAs from Candida species reveal conservation of functional elements. RNA 15: $546-559$.

Heaphy CM, Subhawong AP, Hong SM, Goggins MG, Montgomery EA, Gabrielson E, Netto GJ, Epstein JI, Lotan TL, Westra WH, et al. 2011. Prevalence of the alternative lengthening of telomeres telomere maintenance mechanism in human cancer subtypes. Am J Pathol 179: $1608-1615$.

Hengesbach M, Kim NK, Feigon J, Stone MD. 2012. Single-molecule FRET reveals the folding dynamics of the human telomerase RNA pseudoknot domain. Angew Chem Int Ed Engl 51: 5876-5879.

Kim NK, Zhang Q, Zhou J, Theimer CA, Peterson RD, Feigon J. 2008. Solution structure and dynamics of the wild-type pseudoknot of human telomerase RNA. J Mol Biol 384: 1249-1261.

Kim NK, Theimer CA, Mitchell JR, Collins K, Feigon J. 2010. Effect of pseudouridylation on the structure and activity of the catalytically essential P6.1 hairpin in human telomerase RNA. Nucleic Acids Res 38: 6746-6756.

Kim NK, Zhang Q, Feigon J. 2014. Structure and sequence elements of the CR4/5 domain of medaka telomerase RNA important for telomerase function. Nucleic Acids Res 42: 3395-3408.

Lebo KJ, Zappulla DC. 2012. Stiffened yeast telomerase RNA supports RNP function in vitro and in vivo. RNA 18: 1666-1678.

Leeper TC, Varani G. 2005. The structure of an enzyme-activating fragment of human telomerase RNA. RNA 11: 394-403.

Leeper T, Leulliot N, Varani G. 2003. The solution structure of an essential stem-loop of human telomerase RNA. Nucleic Acids Res 31: 2614-2621.

Lin J, Ly H, Hussain A, Abraham M, Pearl S, Tzfati Y, Parslow TG, Blackburn EH. 2004. A universal telomerase RNA core structure includes structured motifs required for binding the telomerase reverse transcriptase protein. Proc Natl Acad Sci 101: 14713-14718.

Liu F, Kim Y, Cruickshank C, Theimer CA. 2012. Thermodynamic characterization of the Saccharomyces cerevisiae telomerase RNA pseudoknot domain in vitro. RNA 18: 973-991.

Livengood AJ, Zaug AJ, Cech TR. 2002. Essential regions of Saccharomyces cerevisiae telomerase RNA: separate elements for Est1p and Est2p interaction. Mol Cell Biol 22: 2366-2374.

Ly H, Blackburn EH, Parslow TG. 2003. Comprehensive structure-function analysis of the core domain of human telomerase RNA. Mol Cell Biol 23: 6849-6856.

Martin-Rivera L, Blasco MA. 2001. Identification of functional domains and dominant negative mutations in vertebrate telomerase RNA using an in vivo reconstitution system. J Biol Chem 276: 5856-5865.

Mefford MA, Rafiq Q, Zappulla DC. 2013. RNA connectivity requirements between conserved elements in the core of the yeast telomerase RNP. EMBO J 32: 2980-2993.

Merino EJ, Wilkinson KA, Coughlan JL, Weeks KM. 2005. RNA structure analysis at single nucleotide resolution by selective 2 -hydroxyl acylation and primer extension (SHAPE). J Am Chem Soc 127: 4223-4231.

Mihalusova M, Wu JY, Zhuang X. 2011. Functional importance of telomerase pseudoknot revealed by single-molecule analysis. Proc Natl Acad Sci 108: 20339-20344.

Mitchell JR, Collins K. 2000. Human telomerase activation requires two independent interactions between telomerase RNA and telomerase reverse transcriptase. Mol Cell 6: 361-371.

Qi X, Li Y, Honda S, Hoffmann S, Marz M, Mosig A, Podlevsky JD, Stadler PF, Selker EU, Chen JJ. 2013. The common ancestral core of vertebrate and fungal telomerase RNAs. Nucleic Acids Res 41: $450-462$.

Qiao F, Cech TR. 2008. Triple-helix structure in telomerase RNA contributes to catalysis. Nat Struct Mol Biol 15: 634-640.
Richards RJ, Theimer CA, Finger LD, Feigon J. 2006a. Structure of the Tetrahymena thermophila telomerase RNA helix II template boundary element. Nucleic Acids Res 34: 816-825.

Richards RJ, Wu H, Trantirek L, O’Connor CM, Collins K, Feigon J. 2006b. Structural study of elements of Tetrahymena telomerase RNA stem-loop IV domain important for function. RNA 12: 1475-1485.

Seto AG, Livengood AJ, Tzfati Y, Blackburn EH, Cech TR. 2002. A bulged stem tethers Estlp to telomerase RNA in budding yeast. Genes Dev 16: 2800-2812.

Shay JW. 1997. Telomerase in human development and cancer. J Cell Physiol 173: 266-270.

Shefer K, Brown Y, Gorkovoy V, Nussbaum T, Ulyanov NB, Tzfati Y. 2007. A triple helix within a pseudoknot is a conserved and essential element of telomerase RNA. Mol Cell Biol 27: 2130-2143.

Steen KA, Rice GM, Weeks KM. 2012. Fingerprinting noncanonical and tertiary RNA structures by differential SHAPE reactivity. J Am Chem Soc 134: 13160-13163.

Theimer CA, Finger LD, Trantirek L, Feigon J. 2003. Mutations linked to dyskeratosis congenita cause changes in the structural equilibrium in telomerase RNA. Proc Natl Acad Sci 100: 449-454.

Theimer CA, Blois CA, Feigon J. 2005. Structure of the human telomerase RNA pseudoknot reveals conserved tertiary interactions essential for function. Mol Cell 17: 671-682.

Theimer CA, Jády BE, Chim N, Richard P, Breece KE, Kiss T, Feigon J. 2007. Structural and functional characterization of human telomerase RNA processing and cajal body localization signals. Mol Cell 27: 869-881.

Tubbs JD, Condon DE, Kennedy SD, Hauser M, Bevilacqua PC, Turner DH. 2013. The nuclear magnetic resonance of CCCC RNA reveals a right-handed helix, and revised parameters for AMBER force field torsions improve structural predictions from molecular dynamics. Biochemistry 52: 996-1010.

Tzfati Y, Fulton TB, Roy J, Blackburn EH. 2000. Template boundary in a yeast telomerase specified by RNA structure. Science 288: 863-867.

Vulliamy T, Marrone A, Goldman F, Dearlove A, Bessler M, Mason PJ, Dokal I. 2001. The RNA component of telomerase is mutated in autosomal dominant dyskeratosis congenita. Nature 413: 432-435.

Weinrich SL, Pruzan R, Ma L, Ouellette M, Tesmer VM, Holt SE, Bodnar AG, Lichtsteiner S, Kim NW, Trager JB, et al. 1997. Reconstitution of human telomerase with the template RNA component hTR and the catalytic protein subunit hTRT. Nat Genet 17: 498-502.

Wilkinson KA, Merino EJ, Weeks KM. 2006. Selective 2'-hydroxyl acylation analyzed by primer extension (SHAPE): quantitative RNA structure analysis at single nucleotide resolution. Nat Protoc 1: $1610-1616$.

Wu RA, Collins K. 2014. Human telomerase specialization for repeat synthesis by unique handling of primer-template duplex. EMBO J 33: 921-935.

Yeoman JA, Orte A, Ashbridge B, Klenerman D, Balasubramanian S. 2010. RNA conformation in catalytically active human telomerase. J Am Chem Soc 132: 2852-2853.

Zappulla DC, Cech TR. 2004. Yeast telomerase RNA: a flexible scaffold for protein subunits. Proc Natl Acad Sci 101: 1002410029.

Zappulla DC, Goodrich K, Cech TR. 2005. A miniature yeast telomerase RNA functions in vivo and reconstitutes activity in vitro. Nat Struct Mol Biol 12: 1072-1077.

Zappulla DC, Goodrich KJ, Arthur JR, Gurski LA, Denham EM, Stellwagen AE, Cech TR. 2011. Ku can contribute to telomere lengthening in yeast at multiple positions in the telomerase RNP. RNA 17: 298-311.

Zhang Q, Kim NK, Peterson RD, Wang Z, Feigon J. 2010. Structurally conserved five nucleotide bulge determines the overall topology of the core domain of human telomerase RNA. Proc Natl Acad Sci 107: 18761-18768.

Zhang Q, Kim NK, Feigon J. 2011. Architecture of human telomerase RNA. Proc Natl Acad Sci 108: 20325-20332. 
RNA 21: 254-261 (2015)

\section{Refined secondary-structure models of the core of yeast and human telomerase RNAs directed by SHAPE}

RACHEL O. NIEDERER and DAVID C. ZAPPULLA

In the above-noted article, on p. 258, column 2, in the second sentence of the last paragraph, the figure citation "as shown in Figure 2" should be "as shown in Figure 3A."

The authors apologize for this error, and it has been corrected in the versions online. 

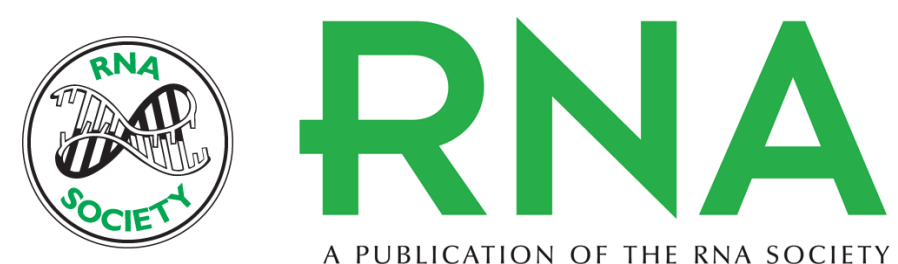

A PUBLICATION OF THE RNA SOCIETY

\title{
Refined secondary-structure models of the core of yeast and human telomerase RNAs directed by SHAPE
}

\author{
Rachel O. Niederer and David C. Zappulla
}

RNA 2015 21: 254-261 originally published online December 15, 2014

Access the most recent version at doi:10.1261/rna.048959.114

\section{Supplemental http://rnajournal.cshlp.org/content/suppl/2014/12/01/rna.048959.114.DC1 \\ Material}

Related Content

References

Creative Commons

License

Email Alerting
Service
Refined secondary-structure models of the core of yeast and human telomerase RNAs directed by SHAPE

Rachel O. Niederer and David C. Zappulla

RNA May , 2015 21: 1053

This article cites 57 articles, 26 of which can be accessed free at: http://rnajournal.cshlp.org/content/21/2/254.full.html\#ref-list-1

Articles cited in:

http://rnajournal.cshlp.org/content/21/2/254.full.html\#related-urls

This article is distributed exclusively by the RNA Society for the first 12 months after the full-issue publication date (see http://rnajournal.cshlp.org/site/misc/terms.xhtml). After 12 months, it is available under a Creative Commons License (Attribution-NonCommercial 4.0 International), as described at http://creativecommons.org/licenses/by-nc/4.0/.

Receive free email alerts when new articles cite this article - sign up in the box at the top right corner of the article or click here.

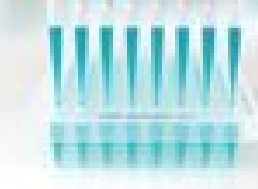

\section{Providing Precise Solutions for} your research.

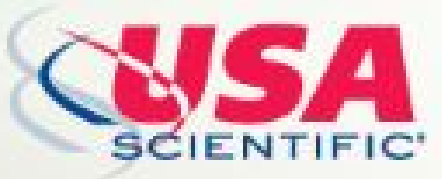

To subscribe to $R N A$ go to:

http://rnajournal.cshlp.org/subscriptions 